\title{
PELAYANAN PRIMA MELALUI PENYELENGGARAAN MAL PELAYANAN PUBLIK DI INDONESIA
}

\author{
Arnita Febriana Puryatama1, Tiyas Nur Haryani2 \\ ${ }_{1}$ Program Studi Ilmu Administrasi Negara Fakultas Ilmu Sosial dan Politik Universitas Sebelas \\ Maret, 2 Program Studi Ilmu Administrasi Negara Fakultas Ilmu Sosial dan Politik Universitas \\ Sebelas Maret \\ e-mail: 2tiyasnurharyani@staff.uns.ac.id
}

\begin{abstract}
Abstrak : Tujuan dari penulisan artikel ini adalah untuk menganalisis pelayanan prima pelayanan publik melalui penyelenggaraan mal pelayanan publik di Indonesia. Metode penelitian yang digunakan adalah deskriptif kualitatif penulis mendeskripsikan keadaan mengenai penyelenggaraan Mal Pelayanan publik sebagai bentuk dari pelaksanaan pelayanan prima dalam reformasi administrasi. Dari hasil analisis, diketahui bahwa pelayanan prima melalui Mal Pelayanan Publik di Indonesia ditandai oleh perubahan pada aspek struktur dan prosedur birokrasi dengan adanya efisiensi administrasi. Selain itu, pelayanan prima dalam aspek reformasi administrasi juga ditandai dengan adanya perubahan dari sisi perilaku dan sikap birokrasi yang condong pada paradigma New Public Service (NPS) yang berorientasi untuk memberikan pelayanan berkualitas kepada masyarakat.
\end{abstract}

Kata kunci: pelayanan prima; pelayanan publik; mal pelayanan publik; reformasi administrasi

Abstract: The purpose of this article is to analyze servive excellent of public services through Public Service Hall implementation in Indonesia. The research method used is descriptive qualitative because the author wants to analyze and describe the ciscumstances of Public services Hall as a form of implementing service excellent on administrative reform. From the results of the analysis, it is known that servive excellent on administrative reforms through Public Service Hall in Indonesia marked by changes in bureaucratic structure and procedures aspects with administrative efficiency. Furthermore, administrative reforms also marked by changes in bureaucratic behavior and attitudes that leans to New Public Services (NPS) paradigm that oriented to providing quality service to the public.

Keyword: administrative reform; public service; public service hall; service excellent,

\section{Pendahuluan}

Pelayanan publik merupakan

kebutuhan dan harapan bagi semua

kalangan masyarakat dan semua negara.

Di Indonesia jaminan atas pelayanan publik bagi warga negaranya tertuang dimulai dari Pembukaan Undang-Undang

Dasar Negara Republik Indonesia Tahun

1945, tubuh Undang-Undang Dasar

Republik Indonesia Tahun 1945 dimulai 
dari pasal 27 sampai dengan pasal 34 membicarakan hak warga negara. Pada pembukaan Undang-Undang Dasar Negara Republik Indonesia Tahun 1945 berbunyi tujuan negara antara lain; melindungi segenap bangsa Indonesia dan seluruh tumpah darah Indonesia, memajukan kesejahteraan umum, mencerdaskan kehidupan bangsa, dan ikut melaksanakan ketertiban dunia yang berdasarkan kemerdekaan, perdamaian abadi, dan keadilan sosial. Maka sangat nyata bahwa pelayanan publik adalah kebutuhan, hak warga negara dan kewajiban negara dalam penyeleggaraannya.

Negara Indonesia melalui sejarah terkait sistem penyelenggaraan pelayanan publik. Awalnya sistem penyelenggaraan publik di Indonesia bersifat sentralisasi. Masa pemerintahan Presiden Soeharto yang telah berlangsung selama 32 tahun memunculkan patologi birokrasi yang menggurita. Pelayanan publik yang berbelit-belit, Korupsi Kolusi dan Nepotisme yang tumbuh subur, spoil system dalam birokrasi pada akhirnya digulingkan oleh gerakan civil society pada Mei 1998. Kejadian gerakan civil society tercatatn dalam sejarah bangsa Indonesia sebagai Reformasi 1998. Pasca Reformasi banyak sekali perubahan sistem penyelenggaraan negara salah satunya perubahan dari sentralisasi ke desentralisasi melalui kebijakan otonomi daerah. Di bawah kepemimpinan Presiden BJ Habibie yang menggantikan Presiden Soeharto pasca reformasi diterbitkan Undang-Undang Republik Indonesia Nomor 22 Tahun 1999 tentang Pemerintahan Daerah sebagai dasar hukum keleluasaan bagi daerah untuk menyelenggarakan kebijakan otonomi daerah. Tindak lanjut berikutnya adalah adanya amandemen kedua dalam UndangUndang Dasar Negara Republik Indonesia Tahun 1945 untuk mempertegas prinsip dan ketentuan desentralisasi di Indonesia dengan munculnya amandemen pasal 18 menjadi pasal 18 A dan 18 B (Hajati, Sri, n.d.). Selanjutnya di tahun 2004 pemerintah Republik Indonesia di bawah masa kepemimpinan Presiden Megawati Soekarno Putri mengganti UndangUndang Republik Indonesia Nomor 22 Tahun 1999 tentang Pemerintahan Daerah menjadi Undang-Undang Republik Indonesia Nomor 32 Tahun 2004 tentang Pemerintahan Daerah. Hal ini menimbang perkembangan keadaan, ketatanegaraan, 
dan tuntutan penyelenggaraan otonomi daerah yang ada.

Perkembangan selanjutnya adalah adanya Undang-Undang Republik Indonesia Nomor 23 Tahun 2014 tentang Pemerintahan Daerah untuk mengganti Undang-Undang Republik Indonesia Nomor 32 Tahun 2004 tentang Pemerintahan Daerah dengan pertimbangan tidak sesuai lagi dengan perkembangan keadaan, ketatanegaraan, dan tuntutan penyelenggaraan pemerintahan daerah. Namun dalam perjalanannya Undang-Undang Nomor 23 tahun 2014 tentang Pemerintahan Daerah mengalami dua kali perubahan. Perubahan pertama diatur dalam UndangUndang Republik Indonesia Nomor 2 Tahun 2015 tentang Penetapan Peraturan Pemerintah Pengganti Undang-Undang Nomor 2 Tahun 2014 tentang Perubahan atas Undang-Undang Nomor 23 Tahun 2014 tentang Pemerintah daerah menjadi Undang-Undang. Perubahan ini berkaitan dengan persoalan pemilihan Gubernur, Bupati dan Walikota yang dilakukan secara langsung. Di tahun 2015 regulasi mengenai pemerintahan daerah kembali mengalami perubahan kedua dengan diterbitkannya Undang-Undang Republik
Indonesia Nomor 9 Tahun 2015 tentang Perubahan Kedua atas Undang-Undang Nomor 23 Tahun 2014 tentang Pemerintahan Daerah. Perubahan kedua. Perubahan kedua dilakukan sebagai tindak lanjut atas adanya regulasi pemilihan Gubernur, Bupati dan Walikota. Dapat kita simak dengan seksama dari sejarah perUndang-Undangan yang telah diterbitkan dalam rangka mengatur pemerintahan daerah menunjukkan bahwa pelaksanaan otonomi daeerah beserta seluruh persoalannya bersifat sangat dinamis.

Apabila berkaca kembali pada latar belakang pertama kali diubahnya sistem sentralisasi ke desentralisasi adalah bertujuan untuk meningkatkan kualitas pelayanan publik kepada setiap masyarakat di daerah. Harapannya desentralisasi dapat mempermudah akses pelayanan publik dan mempercepat hasil dan dampak dari penyelenggaraan pelayanan publik. Seiring berkembangnya desentralisasi tujuan desentralisasi juga berkembang tidak hanya untuk mempermudah akses, tapi juga untuk menghadirkan inovasi pelayanan publik sesuai kebutuhan, kapasitas dan kearifan masing-masing daerah untuk 
mempercepat dan meningkatkan kualitas penyelenggaraan pelayanan publik.

Pada tahun 2009 Indonesia sudah memiliki Undang-Undang Republik Indonesia Nomor 25 Tahun 2009 tentang Pelayanan Publik yang membuka peluang partisipasi pengguna pelayanan publik dalam penyelenggaraan pelayanan publik di Indonesia. Namun, pada kenyataannya sistem administrasi yang dijalankan oleh para aparatur negara dalam penyelenggaraan pelayanan publik saat ini sedikit banyak masih dipengaruhi oleh peninggalan pemerintah di masa kolonial. Patologi birokrasi masih muncul dalam penyelenggaraan pelayanan publik di daerah. Nilai, norma, struktur serta regulasi masih seringkali berorientasi untuk memenuhi kepentingan penguasa daripada pemenuhan kepentingan warga negara (Thoha, 2008). Selaras dengan pendapat tersebut adapula pandangan ahli yang lain bahwa misi utama sistem administrasi dengan paham kolonial tersebut ialah untuk mempertahankan kekuasaan sekaligus untuk mengontrol perilaku individu (Prasojo, 2008). Oleh karena itu tidak heran apabila proses dan struktur yang dibangun dijadikan sebagai sebuah instrumen untuk lebih mengatur dan mengawasi perilaku masyarakat dibanding mengatur dan mengawasi pemerintah dalam menjalankan tugasnya memberi pelayanan pada masyarakat.

Banyak problem penting yang masih terjadi dalam proses penyelenggaran pelayanan publik, misalnya, diskriminasi pelayanan, belum adanya kepastian (uncertainty) waktu dan biaya, serta tingkat kepuasan masyarakat yang masih rendah terhadap pelayanan publik itu sendiri. Pelayanan publik di Indonesia masih rendah dalam aspek tingkat kebijakan maupun implementasinya. Tedapat kecenderungan para birokrat yang menyelenggarakan pelayanan publik menyalahgunakan kekuasaannya dan muncul hubungan patron klien di dalam penyelenggaraan pelayanan publik (Saggaf, Said, dkk, 2018). Dilihat dari segi kualitas pelayanan publik, dilansir dari laman Kementerian Pendayagunaan Aparatur Negara dan Reformasi Birokrasi, dengan salah satu indikasinya dalam Ease of Doing Business (EoDB) pada tahun 2018, Indonesia berada di peringkat ke72 dari 190 negara terkait standar pelayanan meliputi waktu, biaya, dan prosedur (Humas MENPANRB, 2018). Peringkat tersebut tentunya masih 
jauh dari target yang ditetapkan pemerintah yakni di peringkat 40 di tahun 2019 ini.

Kualitas pelayanan publik yang belum menunjukkan peningkatan signifikan tersebut disinggung oleh Kwik Kian Gie (Alfiandri, 2012) yang mengatakan bahwa perbaikan sistem birokrasi belum memperlihatkan kemajuan yang berarti. Hal ini bisa dibuktikan dengan masih maraknya penyalahgunaan kewenangan dan maladministrasi yang dilakukan oleh sebagian oknum penyelenggara negara dalam bentuk Korupsi, Kolusi, Nepotisme (KKN), kualitas pelayanan publik yang rendah, hingga lemahnya fungsi dari lembaga pengawasan. Banyaknya problema yang terjadi dalam pelayanan publik tersebut, maka sudah menjadi keharusan untuk dilakukannya suatu perubahan atau reformasi. Dengan kata lain reformasi administrasi di Indonesia harus segera dijadikan pilihan pemerintah baik pusat maupun daerah untuk mewujudkan pelayanan publik yang berkualitas, pemerintah yang bersih, sehat dan berwibawa (Saggaf, Said, dkk, 2018). Ketersediaan pelayanan publik yang berkualitas merupakan salah satu instrumen yang dapat meningkatkan kepercayaan masyarakat kepada pemerintah yang sekarang mulai berkurang. Bidang layanan publik yang menjadi sasaran utama penyelenggaraan reformasi birokrasi harus bisa menghasilkan progresivitas, baik kualitas maupun kuantitas sehingga dapat menumbuhkan kepuasan, kepercayaan serta dapat meningkatkan kebahagiaan publik.

Reformasi administrasi pelayanan publik dianggap sebagai jalan terbaik untuk mewujudkan sebuah pelayanan yang berkualitas. Pelayanan publik dipilih untuk menjadi mesin utama penggerak reformasi administrasi sebagai upaya dalam rangka mewujudkan nilai-nilai pemerintah yang baik. Kondisi tersebut mendorong pergeseran keinginan publik yang mengharapkan adanya perubahan standar pelayanan publik. Sistem pelayanan yang cepat, efektif serta tepat sasaran harus menjadi patokan pemerintah dalam memberikan pelayanan publik saat ini. Salah satu inovasi yang ditetapkan oleh pemerintah pusat dan daerah dalam penyelenggaraan pelayanan publik adalah membangun sistem Mal Pelayanan Publik (MPP) untuk 
menyatukan pelayanan di publik lintas kewenangan yang sebelumnya tidak mudah untuk dilakukan.

Berdasarkan hal tersebut rumusan masalah yang akan dikaji adalah bagaimana pelayanan prima melalui penyelenggaraan mal pelayanan publik di Indonesia. Sedangkan tujuan dari penulisan artikel ini adalah untuk mendeskripsikan pelayanan prima melalui penyelenggaraan mal pelayanan publik di Indonesia.

\section{Metode Penelitian}

Metode penelitian yang digunakan adalah deskriptif kualitatif. Deskriptif kualitatif merupakan metode penelitan yang berusaha mendeskripsikan seluruh gejala atau keadaan yang ada, yaitu keadaan gejala menurut apa adanya pada saat penelitian dilakukan (Mukhtar, 2013). Data dikumpulkan dengan studi pustaka. Pustaka yang menjadi sumber utama penulisan berasal dari beberapa buku dan artikel jurnal ilmiah yang telah ada sebelumnya dalam topik dan kata kunci yan relevan dengan kajian ini, serta dari sumber berita online yang dapat dipertanggungjawabkan. Metode analisis dilakukan dengan mengkaitkan sumber bacaan yang relevan dengan kajian pustaka. Sehingga pembahasan dan kesimpulan sebagai bagian dari penulisan artikel ini bisa konsisten dan runtut sesuai rumusan masalah yang telah diajukan.

\section{Hasil Penelitian}

\section{Pelayanan Publik}

Istilah pelayanan publik berasal dari Bahasa Inggris yang tersusun dari dua suku kata, yakni: public dan service. Service yang dimaksud di sini bukan to be served, melainkan to serve. Sedangkan kata public sangat tergantung konteks, yang dapat diartikan masyarakat luas, pemerintahan, ataupun segala sesuatu yang menyangkut kepentingan umum yang diselenggarakan oleh pemerintah. Berdasarkan pasal 1 Undang-Undang Republik Indonesia Nomor 25 Tahun 2009 tentang Pelayanan Publik, pelayanan publik didefinisikan sebagai kegiatan atau rangkaian kegiatan dalam rangka pemenuhan kebutuhan pelayanan sesuai dengan peraturan perundang-undangan bagi setiap warga negara pendudukan atas barang, jasa dan pelayanan administratif yang disediakan oleh penyelenggara 
pelayanan publik. Masih dari UndangUndang Republik Indonesia Nomor 25 Tahun 2009 penyelenggara pelayanan publik diartikan setiap institusi penyelenggara Negara, korporasi, lembaga independen yang dibentuk berdasarkan undang-undang untuk kegiatan pelayanan publik dan badan hukum lain yang dibentuk semata-mata untuk kegiatan pelayanan publik

Pelayanan publik dapat berupa pengadaan barang, jasa dan layanan administrasi yang dapat dilakukan oleh; instansi pemerintah yang sebagian atau seluruh dananya bersumber dari APBN dan/atau APBD; dan/atau dari BUMN/BUMD. Bentuk pelayanan publik, yang diberikan kepada masyarakat sebagaimana dimaktubkan pada UU 25/2009 Pasal 5 , dapat dibedakan atas beberapa jenis layanan; pertama, Pelayanan Administratif yaitu pelayanan yang menghasilkan berbagai bentuk dokumen resmi yang dibutuhkan oleh publik, misalnya status kewarganegaraan, sertifikat kompetensi, kepemilikan atau penguasaan terhadap suatu barang dan sebagainya. Dokumen-dokumen ini antara lain Kartu Tanda Penduduk (KTP), Akta Pernikahan, Akta kelahiran, Akta Kematian, Buku Pemilik Kendaraan Bermotor. BPKB), Surat Ijin Mengemudi (SIM), Surat Tanda Kendaraan Bermotor (STNK), Ijin Mendirikan Bangunan (IMB), Paspor, Sertifikat Kepemilikan/Penguasaan Tanah dan sebagainya. Kedua, Pelayanan Barang, yakni pelayanan yang menghasilkan berbagai bentuk/jenis barang yang digunakan oleh masyarakat. Misalnya jaringan telepon, jaringan kelistrikan serta air bersih. Ketiga, Pelayanan Jasa yakni pelayanan yang mengahsilkan berbagai bentuk jasa yang diperlukan oleh publik. Misalnya pendidikan, pelayanan kesehatan, penyelenggaraan transportasi serta jasa pos (pengiriman barang).

Pelayanan publik memiliki tujuan yang sering kita harapkan yakni untuk memuaskan masyarakat sebagai pengguna layanan. Menurut (Sinambela, 2008) secara teoritis tujuan pelayanan publik pada dasarnya adalah untuk memuaskan masyarakat. Untuk mencapai kepuasan itu menurut 
(Sinambela, 2008) dituntut kualitas pelayanan prima yang tercermin dari: golongan, status sosial, dan lainlain. a. Transparan. Pelayanan yang bersifat terbuka, mudah dan dapat diakses oleh semua pihak yang membutuhkan dan disediakan secara memadai serta mudah dipahami.

b. Akuntabilitas. Pelayanan yang dapat dipertanggungjawabkan sesuai dengan ketentuan peraturan perundang-undangan.

c. Kondisional. Pelayanan yang sesuai dengan kondisi dan kemampuan pemberi dan penerima pelayanan dengan tetap berpegang kepada prinsip evisiensi dan efektivitas.

d. Partisipatif. Pelayanan yang dapat mendorong peran serta masyarakat dalam penyelenggaraan pelayanan publik dengan memperhatikan aspirasi, kebutuhan dan harapan masyarakat.

e. Kesamaan Hak. Pelayanan yang tidak melakukan diskriminasi dilihat dari aspek apapun khususnya suku, ras, agama,

\section{Sejarah Mal Pelayanan Publik}

Penyelenggaraan Mal Pelayanan Publik (MPP) di Indonesia terinspirasi dari Public Service Hall (PSH) Georgia dan Asan Xidmat Azerbaijan di mana keduanya telah menandatangi $\mathrm{MoU}$ kerjasama dengan Kementerian Pendayagunaan Aparatur Negara dan Reformasi Birokrasi (KEMENPAN RB) dalam rangka penguatan kelembagaan serta peningkatan sumber daya aparatur. Di PSH Georgia sendiri sudah ada 12 layanan kementerian/lembaga yang telah terintegrasi, seperti kemudahan berusaha mulai dari kemudahan pendaftaran usaha, inhouse notary hingga perolehan hak atas tanah, selain itu juga kemudahan bagi urusan pengesahan pernikahan. Mereka mempunyai tagline "every services just 15 minutes". Kemudian di Axan Xidmat, Azerbaijan, merupakan lembaga pelayanan publik yang telah memadukan antara pelayanan dari pemerintah dengan swasta untuk kepentingan bisnis. 
Belajar dari hal tersebut yang kemudian disesuaikan dengan konteks Indonesia, KEMENPAN RB menyelenggaran Mal Pelayanan Publik (MPP) yang dianggap lebih progresif dalam memadukan pelayanan dari pemerintah pusat, daerah hingga swasta dalam satu tempat. Hal tersebut dianggap masih sulit karena kita semua tahu bahwa birokrasi di Indonesia sangat besar. Hingga pada akhir pertengahan 2019, melalui payung regulasi Peraturan Menteri Pendayagunaan Aparatur Negara dan Reformasi Birokrasi Republik Indonesia Nomor 23 Tahun 2017 tentang Penyelenggaraan Mal Pelayanan Publik, kini telah diresmikan sebanyak 14 MPP yang sudah dapat beroperasi dengan baik.

Mal Pelayanan Publik sendiri merupakan pelayanan terpadu generasi ketiga yang dianggap sebagai langkah pembaharuan bagi sistem administrasi pelayanan publik di Indonesia. Mal Pelayanan Publik adalah suatu kegiatan atau aktivitas penyelenggaraan pelayanan publik atas barang, jasa dan/atau pelayanan administrasi dengan mengintegrasikan sistem pelayanan publik dan merupakan perluasan fungsi pelayanan terpadu yang diberikan oleh pemerintah, baik Pusat maupun Daerah dimana pelayanan satu sama lain terdapat keterkaitan dalam satu lokasi atau gedung tertentu yang dikombinasikan dengan kegiatan jasa dan ekonomi lainnya (Umam, 2020).

MPP dinilai lebih progresif memadukan pelayanan dari pemerintah pusat, daerah hingga swasta serta pelayanan Badan Usaha Milik Negara/ Badan Usaha Milik Daerah/ swasta yang dimaksudkan untuk membuat postur pelayanan menjadi lebih cepat, mudah, terjangkau, aman dan nyaman yang terpusat pada satu bangunan. Perlu diketahui bahwa generasi pertama layanan terpadu di Indonesia yakni Pelayanan Terpadu Satu Atap (PTSA), kemudian dari PTSA berevolusi menjadi Pelayanan Terpadu Satu Pintu (PTSP) sebagai generasi kedua. Kehadiran MPP selanjutnya tidak lantas mematikan PTSP di generasi sebelumnya, namun justru peran PTSP ini diperluas dengan adanya MPP. Konsep dari Mal Pelayanan Publik ini 
sendiri yaitu mengintegrasikan segala jenis pelayanan dalam satu gedung (Umam, 2020).

Kehadiran MPP tidak lantas mendegradasi PTSA sebagai generasi pendahulunya. Masih ada beberapa kendala PTSA yang harus disempurnakan, beberapa di antaranya mengenai perizinan yang dulunya masih bergantung pada dinas teknisnya yang menyebabkan kemungkinan keterlambatan proses, kemudian ada juga mengenai beberapa pemerintah daerah yang belum memiliki sertifikasi ISO yang memungkinkan ada celah tidak terkontrol serta tidak transparan yang memicu munculnya temuan penyelewengan dari lembaga pengawasan.

Pembentukan MPP ditujukan untuk; a. memberikan kemudahan, kecepatan, keterjangkauan, keamanan, dan kenyamanan kepada masyarakat dalam mendapatkan pelayanan; dan $b$. meningkatkan daya saing global dalam memberikan kemudahan berusaha di Indonesia (Anwar, 2018). Sampai dengan awal tahun 2020 sudah terdapat 22 MPP di berbagai daerah di
Indonesia. Ke-22 MPP tersebut terdapat di Provinsi DKI Jakarta, Kota Surabaya, dan Kabupaten Banyuwangi pada 2017. Lalu Kota Denpasar, Kota Tomohon, Kabupaten Karangasem, Kabupaten Badung, Kota Batam, Kabupaten Probolinggo, Kota Padang, serta Kabupaten Kulon Progo telah diresmikan di tahun 2018. Kemudian pada 2019 ini, MPP diresmikan di Kabupaten Banyumas, Kabupaten Sidoarjo, Kabupaten Sumedang, Kota Samarinda, Kota Payakumbuh, Kota Banda Aceh, Kota Pekanbaru serta Kabupaten Sleman. Pada tahun 2020 diresmikan di Kabupaten Barru, Kota Palembang, dan Kabupetan Batang. Sementara di beberapa kota dan kabupetan yang lain masih tahap komitmen pendirian mal pelayanan publik dan pembangunan mal pelayanan publik. 


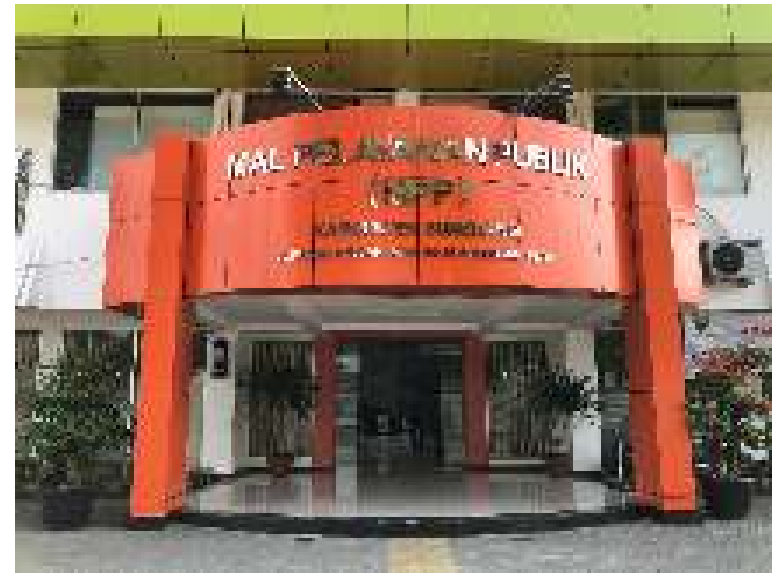

Gambar 1. Gedung Mal Pelayanan

Publik Kabupeten Sumedang

Sumber: (Humas MENPANRB, 2019b)

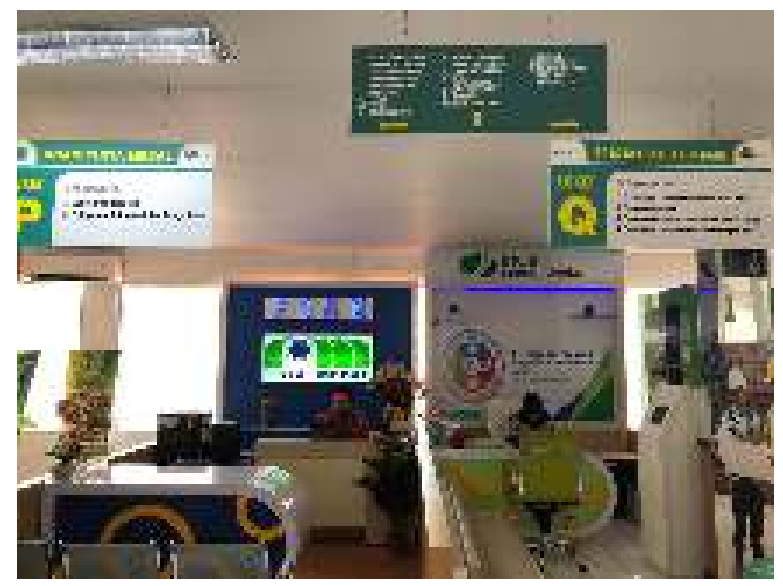

Gambar 2. Wujud Pelayanan di Mal Pelayanan Publik Kabupeten Sumedang Sumber: (Humas MENPANRB, 2019b)

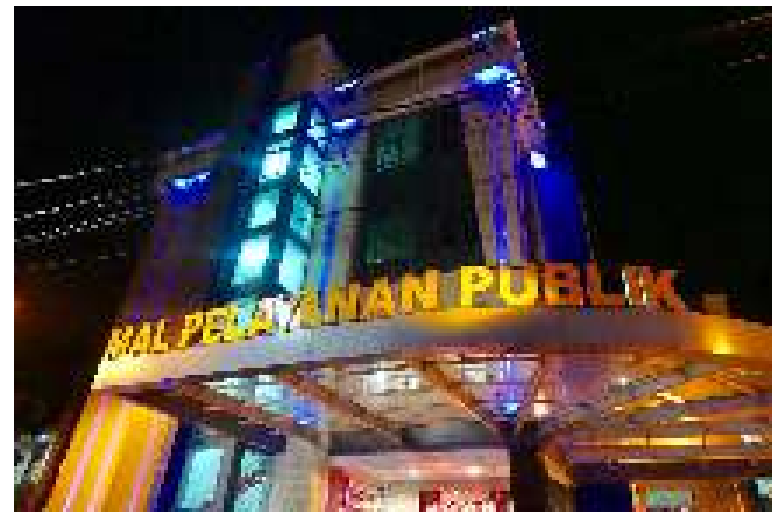

Gambar 3. Gedung Mal Pelayanan Publik Kota Samarinda Sumber: (Humas MENPANRB, 2019a)

\section{Pembahasan}

Semakin berat dan kompleksnya tantangan yang dihadapi Bangsa Indonesia di era global saat ini, megedepankan pembaharuan dengan gagasan-gagasan yang inovatif dan produktif pada lembaga pemerintah baik pusat maupun daerah adalah langkah dan sikap yang tepat dan selayaknya memperoleh dukungan dari semua komponen masyarakat.

Hadirnya Mal Pelayanan Publik menambah warna baru bagi sejarah reformasi administrasi pelayanan publik di Indonesia. Pertama, pada aspek struktur serta prosedur birokrasi. Dengan terselenggaranya MPP, prosedur birokrasi yang sebelumnya dianggap berbelit-belit kini mampu disederhanakan karena sudah ada standar pelayanan waktu yang 
telah ditentukan. Di dalam yang membuka layanan serupa

penyelenggaraan MPP, integrasi data dan sistem informasi terpadu sangat dibutuhkan untuk mewujudkan efisisensi pelayanan. Cara-cara yang diterapkan meliputi penyelarasan sistem operasional prosedur (SOP), penyelasaran standar pelayanan, pemanfaatan data tunggal, serta penguatan layanan berbasis teknologi informasi (e-Services). $\begin{array}{lll}\text { Perbaikan dalam } & \text { sistem }\end{array}$ penyelenggaraannya pun tentunya harus didukung oleh perbaikan institusi yang menjadi bagian dalam penyelenggaraan MPP. Beberapa restrukturisasi organisasi pun dilakukan dengan menintegrasikan antara layanan administrasi lokal dengan layanan administrasi kementerian dalam satu gedung. Misalnya, di MPP DKI Jakarta terdapat 328 layanan adminstrasi yang terdiri dari gabungan layanan Kementerian atau lembaga, yakni 296 berasal dari Pemda DKI, 32 lainnya dari tujuh kementerian maupun lembaga. Dari Pemda DKI sendiri menyediakan layanan dari Badan Pajak dan Retribusi Daerah, Dinas Kependudukan dan Pencatatan Sipil, serta Dinas Cipta Karya, Tata Ruang dan Pertanahan. Adapun dari kementerian, lembaga, dan perusahaan diantaranya, unit layanan Ditjen Pajak, Ditjen Bea dan Cukai, Ditjen Imigrasi, PT. Jasa Raharja, hingga PT. PLN (Persero).

Pengintegrasian layanan dalam satu gedung ini mempercepat proses pelayanan warga dalam mengurus perizinan dan non-perizinan. masyarakat tidak harus menggunakan metode antrean manual, melainkan bisa mengambil nomor antrean secara online. Selain itu, MPP memungkinkan masyarakat tidak lagi harus berpindah-pindah lokasi untuk membuat izin usaha. Seperti, membuat Nomor Pokok Wajib Pajak (NPWP) ke kantor Ditjen Pajak, lalu memesan nama perusahaan ke Ditjen Administrasi Hukum Umum (AHU) Kemenkumham, hingga kemudian harus mengurus Surat Izin Usaha Perdagangan (SIUP) dan Tanda Daftar Perusahaan (TDP) ke Dinas PTSP. Belum lagi pengurusan BPJS Kesehatan dan Ketenagakerjaan untuk para pegawainya.

Dengan adanya MPP, sekarang masyarakat cukup datang ke satu lokasi untuk mengurus itu semua. Ini adalah sebuah lompatan dalam pelayanan publik, dari yang sebelumnya berpisah dan menyebar sekarang berkumpul dalam 
satu lokasi yang sama. Untuk ruang pelayanan MPP, di DKI Jakarta misalnya MPP mencakup tiga lantai. Dengan rincian lantai 1 terdiri dari lobi, tempat resepsionis, area tunggu, loket pelayanan, ATM, layanan bagi difabel, layanan kilat, self service counter, dan loket pengambilan. Sedangkan lantai 2 terdiri dari loket pelayanan, ruang prioritas, ruang konsultasi, ruang menyusui, area bermain anak dan Pojok Testimoni. Kemudian untuk lantai 3 berisi unit-unit pelayanan dari Kementerian, lembaga negara, BUMN, dan BUMD.

Sebuah pelayanan yang bisa disebut dengan "everything in one place" ini diyakini dapat semakin mempercepat proses pelayanan warga dalam mengurus perizinan dan non-perizinan. Hal tersebut sebagai upaya mencapai tujuan internal dari reformasi administrasi yakni dalam hal efisiensi administrasi yang mencakup penghematan uang, penyederhanaan formulir dan prosedur sehingga memungkinkan efisiensi waktu, serta penghilangan duplikasi karena pemanfaatan data tunggal. Sebagai contoh, dalam perpanjangan pasport di MPP DKI Jakarta, pemohon hanya perlu melampirkan KTP serta paspor lama, tidak lagi harus melampirkan akta kelahiran dan kartu keluarga. Biaya serta waktu juga telah menunjukan adanya kepastian (certainty), sehingga sudah ada batasan prosedur yang jelas .

Kedua, dilihat dari aspek perilaku dan sikap birokrat. Aspek perilaku dan sikap para birokrat ini sering mendapat sorotan kritis dari masyarakat. Obsesi para birokrat dan politisi menjadikan birokrasi sebagai lahan untuk memenuhi hasrat dan kekuasaan (power culture) dan kultur korupsi, kolusi dan nepotisme (KKN) menjadi hal yang umum terjadi (Prasojo, 2008). Oleh karena itu, saat ini pemerintah daerah terus didorong untuk dapat membangun Mal Pelayanan Publik masing-masing. MPP juga harus dilengkapi dengan berbagai fasilitas ramah difabel serta fasilitas lain seperti ruang laktasi, serta tempat bermain anak.

MPP juga merupakan salah satu wujud nyata Gerakan Indonesia Melayani. Sebagai contoh, MPP DKI Jakarta kini memiliki budaya pelayanan yang berkomitmen untuk memberikan pelayanan pelayanan berkualitas kepada warganya dengan berpegang teguh pada nilai-nilai SETIA (Solusi, Empati, Tegas, Inovatif dan Andal). Komitmen 
memberikan pelayanan berkualitas kepada masyarakat merupakan usaha mewujudkan tujuan dari adanya reformasi administrasi melalui penghapusan kelemahan dan patologi administrasi seperti korupsi dan pilih kasih dalam memberikan pelayanan. Ini selaras dengan prinsip New Public Service (NPS). NPS menghendaki adanya perubahan orientasi mengenai posisi warga negara. Warga negara semestinya ditempatkan di depan serta menekankan bagaimana membangun institusi publik untuk melayani warga negara berdasarkan integritas dan responsivitas (Wijaya, 2014). Mal Pelayanan Publik menjadi media untuk membangun sistem kerja dan sinergi yang utuh, menunjukkan wajah baru birokrasi yang mengadopsi New Public Service, hal ini tentu akan mendorong kesejahteraan masyarakat (Umam, 2020).

\section{Kesimpulan}

Pelayanan prima melalui pelayanan publik ditunjukkan dengan adanya perubahan dari sisi struktur dan prosedur birokrasi dengan adanya efisiensi administrasi. Perubahan dalam hal reformasi administrasi ini dapat dilihat dari adanya restrukturisasi dan pengintegrasian layanan yang dilakukan oleh pemerintah daerah tempat diselenggarakannya MPP dengan lembaga pemerintah pusat setingkat kementerian. Prosedur birokrasi pun sekarang telah disederhanakan dengan memangkas alur birokrasi dengan pelayanan "everything in one place" serta penggunaan data tunggal untuk menghindari duplikasi data. Perubahan lain juga dapat dilihat dari aspek perilaku dan sikap birokrat yang mengarah pada New Public Service (NPS) dengan komitmen memberikan pelayanan berkualitas kepada masyarakat.

Meskipun Penyelenggaraan MPP merupakan langkah strategis sebagai wujud reformasi administrasi untuk mewujudkan sebuah pelayanan publik yang berkualitas di Indonesia. Namun, tidak dipungkiri bahwa efektivitas MPP masih mengalami beberapa kendala selama kantor tersebut masih mengandalkan tenaga manusia dalam mengurus administrasi dan menerbitkan izin. Diharapkan ke depannya semua Mal Pelayanan Publik yang sudah berdiri dapat menyediakan layanan dengan sistem online yang disebut online Single Submission (OSS) untuk lebih mudah 
memberikan layanan di bidang perizinan maupun non perizinan. Apalagi MPP didukung dengan penggunaan data tunggal yang mengintegrasikan medianya sebagai data sharing.

\section{Daftar Pustaka}

Alfiandri, A. (2012). Reformasi Birokrasi di Era Otonomi Daerah. SOSIORELIGIA, 10(1).

Anwar, M. K. (2018). Implentasi Mal Pelayanan Publik/ MPP Mewujudkan Kota Ramah Pelayanan Publik/ KRPP. Prosiding Seminar Nasional Kebijakan Dan Perencanaan Kota Berwawasan Kesehatan, 151-162.

Hajati, Sri, D. (n.d.). Buku Ajar Politik Hukum Pertanahan. Airlangga University Press.

Humas MENPANRB. (2018). Kementerian PANRB Gelar Survey Kemudahan Berusaha di $10 \quad$ Kota. https://www.menpan.go.id/site/beri ta-terkini/kementerian-panrb-gelarsurvey-kemudahan-berusaha-di-10kota

Humas MENPANRB. (2019a). Mal Pelayanan Publik Samarinda Siap Diresmikan.

https://www.menpan.go.id/site/beri ta-terkini/mal-pelayanan-publiksamarinda-siap-diresmikan

Humas MENPANRB. (2019b). Mal Pelayanan Publik Sumedang, Jembatan Antara Masyarakat dengan Pemerintah.

https://www.menpan.go.id/site/beri ta-terkini/mal-pelayanan-publiksumedang-jembatan-antaramasyarakat-dengan-pemerintah

Mukhtar. (2013). Metode Praktis Penelitian Deskriptif Kualitatif.
Referensi (GP Press Group).

Prasojo, E. \& T. K. (2008). Reformasi Birokrasi dan Good Governance: Kasus Best Practices dari Sejumlah Daerah di Indonesia. $5 \mathrm{Th}$ International Symposium of Jurnal Antropologi Indonesia, Banjarmasin, 1-15.

Saggaf, Said, dkk, . (2018). Reformasi Pelayanan Publik di Negara Berkembang. CV Sah Media.

Sinambela, L. P. (2008). Reformasi Pelayanan Publik: Teori, Kebijakan, dan Implementasi. PT Bumi Aksara.

Thoha, M. (2008). Birokrasi Pemerintah Indonesia di Era Reformasi. Kencana Prenada Media.

Umam, U. dan A. (2020). Efektivitas Mal Pelayanan Publik (MPP) Kementerian Pendayagunaan Aparatur Negara dan Reformasi Birokrasi dalam Pelaksanaan Pelayanan Publik. Jurnal Humaniora, Vol.4(No.1 April 2020), 160-165.

Wijaya, A. F. \& D. O. R. (2014). Manajemen Publik: Praktik dan Teori. Universitas Brawijaya Press. 